Note

\title{
Stingless bees damage broccoli inflorescences when collecting fibers for nest building
}

\author{
Adriano Jorge Nunes dos Santos§, Sônia Maria Forti Broglio, Nivia da Silva Dias-Pini१*, Leilianne Alves de Souza, Tiago Jorge de \\ Araújo Barbosa
}

UFAL - Depto. de Fitossanidade, BR 104 Norte, km 85 - 57100-000 - Rio Largo, AL - Brasil.

*Corresponding author <nivia@cnpat.embrapa.com>

Edited by: Richard V. Glatz

Received March 18, 2011

Accepted Dezember 21, 2011

\begin{abstract}
The stingless bee Trigona spinipes (Fabricius, 1793) (Hymenoptera: Apidae) is an important pollinator for various crops, but constitutes an occasional pest of other plant species since it causes injury to leaves, stems, flowers and fruits while collecting nest materials. The aim of the present study was to determine the damage caused by $T$. spinipes to a broccoli (Brassica oleracea L. var. italica, Brassicaceae) growing on an organic farm. A significant number of plants $(72.5 \%)$ presented damaged inflorescences, while $39 \%$ of all of the inflorescences suffered some degree of injury. The activities of $T$. spinipes caused scarifications on the stems of the inflorescences, and these typically evolved to epidermal cicatrices up to $10 \mathrm{~mm}$ wide. In some cases, the lesions were sufficiently deep to cause partial destruction of the vascular tissues, and this lead to thinner ( $<5 \mathrm{~mm}$ diameter) floral stems that may collapse. To the best of our knowledge, this is the first report concerning the attack of broccoli plants by T. spinipes. The results obtained should serve to highlight the possibility that stingless bees could be responsible for direct and/or indirect damage to vegetable crops, and to stimulate the development of control strategies for these incidental pests.

Keywords: Trigona spinipes, occasional pest, pest control
\end{abstract}

\section{Introduction}

The consumption of vegetables has been increasing substantially every year, reflecting the growing demand for more nutritious and healthier foods. The sale of broccoli (Brassica oleracea L., Brassicaceae), for example, has risen in Brazil steadily from 2007 to reach 11,595 tons, whilst the production increased by $11.57 \%$ in 2009 in comparison with 2008. Consumer demand for broccoli remains strong, and that the market for the vegetable is likely to continue to grow in the years to come (Informa Economics FNP, 2011). As for any other crop, however, the productivity of broccoli is influenced by various factors, one of the most important of which is the activity of insect pests such as lepidopterans and aphids (Machado et al., 2007).

The stingless bee Trigona spinipes (Fabricius, 1793) (Hymenoptera: Apidae, Meliponinae) is distributed widely within Brazil, where it is known as "irapuá", "arapuá" or "abelha-cachorro" (the dog bee), and has been reported on more than 600 host species (Nava et al., 2009). As is typical species of the Meliponini, T. spinipes are social insects and live in perennial colonies, which may contain several thousands of individuals and comprise a mated queen, other virgin queens, workers, drones, larvae and pupae (Vieira et al., 2007). The nests of this bee are constructed from plant fragments and resins, and are normally located on walls or branches of trees. The internal chamber (honeycomb) of the nest is divided into cells of different shapes and sizes, and contains the

sPresent address: UFLA - Depto. de Entomologia, C.P. 303 - 37200-000 Lavras, MG - Brasil.

IPresent address: Embrapa Agroindústria Tropical, 60511-110 - Fortaleza, CE - Brasil. brood (eggs, larvae, and pupae) together with the store of honey and pollen (Camargo and Pedro, 2003).

Stingless bees are important pollinators of a wide variety of plant species and the insects have even been commercialized to fulfill this function (Sanchez et al., 2001). On the other hand, some anecdotal evidence suggests that $T$. spinipes may inflict damage to specific plants while collecting nest materials, although the details of such behavior are not well-documented (Nava et al., 2009). In contrast, Silveira et al. (2010) identified T. spinipes as the agent responsible for the destruction of flowers, fruits, leaves and shoots of rabbiteye blueberry plants (Vaccinium ashei, Ericaceae). It has also been claimed that the bees scarify fruits and spoil the pulp of passion fruit (Passiflora sp., Passifloraceae), apparently rendering the products unacceptable for commercialization (Rodrigues Netto and Berlote, 1996). Sacramento et al. (2007) described the damage caused by T. spinipes to buds and developing fruits of purple mangosteen (Garcinia mangostana, Guttiferae). In this case, the lesions present on the surface of the fruits exuded a yellow resin and the fruits became wrinkled. Attacks on pigeon pea (Cajanus cajan, Fabaceae) crops by T. spinipes have also been reported (Azevedo et al., 2008).

Considering the unexpected behavior of T. spinipes, the aim of the present study is to extend the list of species attacked by this non stinging bee and to report the damage inflicted on broccoli plants $(B$. oleracea $L$. var. italica Plenck) cultivated under an organic system.

\section{Materials and Methods}

The study site was an organic farm located in Ara-

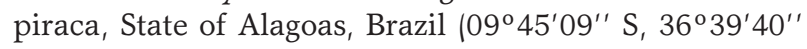


W; $264 \mathrm{~m}$ altitude), with an organic certification issued by Ecocert Brasil ${ }^{\circledR}$. Observations started in June 2010, 45 days after the transplantation of broccoli plants into the field, and were conducted during morning periods ( $8 \mathrm{~h} 00$ to $12 \mathrm{~h} 00)$ throughout the entire production season (60 days). In order to quantify the damage caused to the broccoli crop by $T$. spinipes, the following parameters were assessed: number of observed plants, number of plants presenting inflorescences, number of inflorescences per plant, total number of damaged inflorescences, number of plants presenting damaged inflorescences, and number of damaged inflorescences per plant. The number of observed plants $(n=200)$ accounted for the entire crop. The evaluated plants $(n=40)$ were selected randomly. The corresponding percentage values were calculated from these observations. Photographic images of bee-infested plants and of damaged inflorescences were recorded.

\section{Results and Discussion}

Figure 1A shows a broccoli inflorescence that was infested by $T$. spinipes. The bees caused injuries to the plants by scratching the epidermis of the floral peduncle with their mandibles (Figure 1B) and inflicting scarifications over the length of the inflorescence stem (Figure 1C), which lesions typically evolved to epidermal cicatrices approximately $10 \mathrm{~mm}$ wide. In some cases, the wounds were sufficiently deep to provoke the partial destruction of the vascular tissues, thus restricting the supply of water and nutrients and causing the floral stems, particularly the thin ones $1<5 \mathrm{~mm}$ diameter), to collapse (Figure 1D). Superficial scratches and deep lesions could be observed as isolated injuries or co-occurrences, and in some examples they covered more than $50 \%$ of the stem width. In some cases, however, only the floral axis was attacked while the stems remained intact and exhibited characteristics that were still commercially acceptable.

Lepidopteran larvae and aphids were present in the crop. However, these insects did not cause the reported damage. The damage was unique and specific to T. spinipes. In the $T$. spinipes-infested broccoli crop a significant number of plants $(72.5 \%)$ presented damaged inflorescences, and $38.3 \%$ of all of the inflorescences were found to have suffered some degree of injury (Table 1). These results provide an indication of the magnitude of the broccoli yield loss caused by the stingless bees in terms of productivity and revenue. However, there are two important issues that have to be taken into account when considering the generality of these findings: (i) it is possible that the studied pesticide-free crop favored the presence of the insect; and (ii) a lack of alternative sources of food and nest material (including fiber and
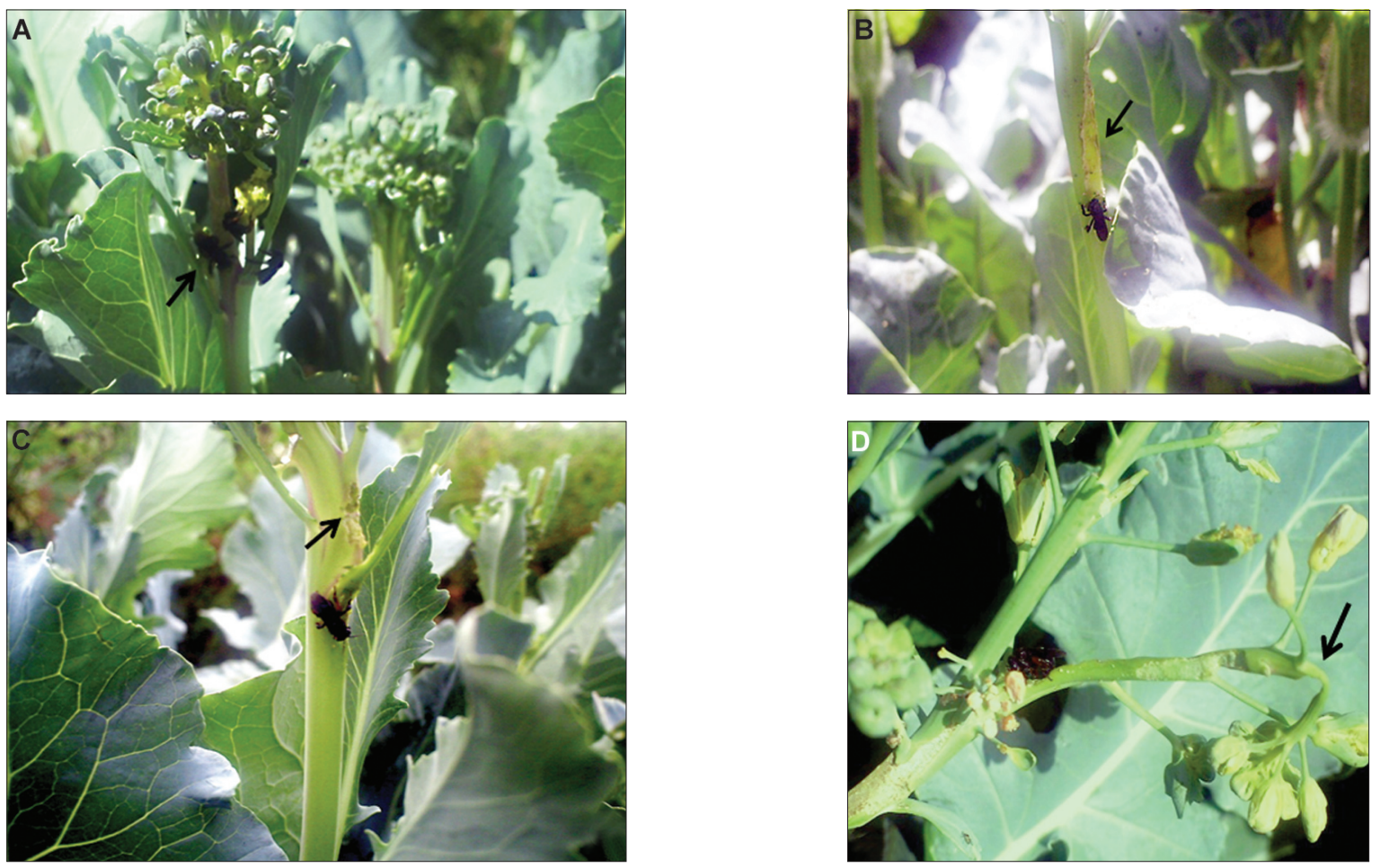

Figure 1 - Infestation and damage of Broccoli by Trigona spinipes. Important aspects are indicated by arrows. A) T. spinipes individual on stem of Broccoli inflorescence; B) Epidermis of the floral peduncle scratched; C) Scarifications over the length of the inflorescence stem; D) Tipping of the floral stems. 
Table 1 - Level of measured damage to broccoli (Brassica oleracea) by stingless bees of the species Trigona spinipes. Data collected during June and July 2010. The sample population $(n=40)$ was derived from a total population of $(n=200)$ plants that presented inflorescences.

\begin{tabular}{lcc}
\hline Parameter & Number observed & $\%$ \\
\hline $\begin{array}{l}\text { Plants presenting damaged } \\
\text { inflorescences }(n=40)\end{array}$ & 29 & 72.5 \\
$\begin{array}{l}\text { Damaged inflorescences } \\
(n=146)\end{array}$ & 56 & 38.3 \\
$\begin{array}{l}\text { Mean damaged inflorescences } \\
\text { per plant }(n=3.6)\end{array}$ & 1.9 & 52.8 \\
\hline
\end{tabular}

resin) could have stimulated the observed foraging behavior. In this context, T. spinipes has been considered an incidental pest of grapevine crops during summer periods when alternative food sources were not abundant (Hickel, 1998).

An investigation of the biodiversity of insects associated with pigeon pea crops in the State of Bahia, Brazil (Azevedo et al., 2008), revealed that $T$. spinipes constantly visited aggregations of sap-sucking Membracidae, particularly Enchenopa gracilis (Germar, 1821), in order to collect exudate (honeydew). It is therefore suggested that it would be possible to control the attack of T. spinipes by monitoring the presence of Meliponini on a crop and offering alternative fiber sources as appropriate. Certain$l y$, the application of insecticides is not recommended for the control of these atypical pests of broccoli since T. spinipes is not only an important pollinator but also produces honey. The destruction of Meliponini nests has been suggested (EMBRAPA, 2011) but such an approach does not fall within the principles of ecological organic farming and, hence, does not constitute a viable option for the broccoli crop.

To the best of our knowledge, this is the first report concerning the attack of broccoli plants by $T$. spinipes and is of particular importance for three key reasons: (i) it serves to highlight the possibility that stingless bees could be responsible for direct damage to vegetable crops; (ii) it draws attention to the possibility of indirect damage, given that tissues that have been wounded by bees are likely to provide entry points for phytopathogens, and (iii) it stimulates the development of control strategies for this incidental pest.

\section{Acknowledgements}

To Dr. Carlos Alfredo Lopes de Carvalho /Centro de Ciências Agrárias, Ambientais e Biológicas, Universidade Federal do Recôncavo da Bahia) for the identification of $T$. spinipes.

\section{References}

Azevedo, R.L.; Carvalho, C.A.L.; Marques, O.M. 2008. Insects associated to the pigeonpea crop in the Recôncavo region of Bahia, Brazil. Revista Caatinga 21: 83-88 (in Portuguese, with abstract in English).

Camargo, J.M.F.; Pedro, S.R.M. 2003. Neotropical Meliponini: the genus Partamona Schwarzn, 1939 (Hymenoptera, Apidae, Apinae); bionomy and biogeography. Revista Brasileira de Entomologia 47: 311-372 (in Portuguese, with abstract in English).

Empresa Brasileira de Pesquisa Agropecuária [EMBRAPA]. 2011. Passion fruit. Embrapa Mandioca e Fruticultura, Cruz das Almas, BA, Brazil. Available at: http://www.cnpmf.embrapa. br/index.php? $\mathrm{p}=$ pesquisa-culturas_pesquisadas-maracuja. php\&menu $=2$ [Accessed Jul. 20, 2011]

Hickel, E.R. 1998. Grapevine pests. p. 191-209. In: BragaSobrinho, R.; Cardoso, J.E.; Freire, F.C.O., eds. Tropical fruit pests in agroindustrial importance. EMBRAPA/Centro Nacional de Pesquisa de Agroindústria Tropical, Brasília, DF, Brazil (in Portuguese).

Informa Economics FNP. 2011. Agrianual Anuário da Agricultura Brasileira. Informa Economics FNP, São Paulo, SP, Brazil. (in Portuguese)

Machado, L.A.; Silva, V.B.; Oliveira, M.M. 2007. Use of plant extracts in pest control in horticultural. Biológico 69: 103-106 (in Portuguese).

Nava, D.E.; Zanardi, O.Z.; Melo, M.; Silva, S.D.A.E. 2009. Pest and beneficial insects for culture of tung. Embrapa Clima Temperado, Pelotas, RS, Brazil (in Portuguese).

Rodrigues Netto, S.M.; Berlote, L.C.C. 1996. Incidence of Trigona spinipes (Fabr., 1793) (Hymenoptera: Apidae) in passion fruit (Passiflora sp.). O Biológico 58: 13-14 (in Portuguese).

Sacramento, C.K.; Coelho Júnior, E.; Carvalho, J.E.U.; Müller, C.H.; Nascimento, W.M.O. 2007. Growing mangosteen in Brazil. Revista Brasileira de Fruticultura 29: 195-203 (in Portuguese, with abstract in English).

Sanchez, A.L.; Slaa, E.J.; Sandi, M.; Salazar, W.; Benedek, P.; Richards, K.W. 2001. Use of stingless bees for commercial pollination in enclosures: a promise for the future. Acta Horticulturae 561: 219-223.

Silveira, T.M.T.; Raseira, M.C.B.; Nava, D.E.; Couto, M. 2010. Damage influence of the irapuá bee on blueberry flower over the effective fruit production and the fruits. Revista Brasileira de Fruticultura 32: 303-307 (in Portuguese, with abstract in English).

Vieira, C.U.; Rodovalho, C.M.; Almeida, L.O.; Siquieroli, A.C.S.; Bonetti, A.M. 2007. Interaction between Trigona spinipes Fabricius, 1793 (Hymenoptera: Apidae) and Aethalion reticulatum Linnaeus, 1767 (Hemiptera: Aethalionidae) in Mangifera indica (Anacardiaceae). Bioscience Journal 23: 10-13 (in Portuguese, with abstract in English). 